\title{
EPIDEMIOLOGY OF SPINAL CORD INJURY IN REFERENCES TRAUMA CENTER IN CURITIBA (PARANÁ, BRAZIL)
}

\author{
EPIDEMIOLOGIA DO TRAUMA RAQUIMEDULAR (TRM) EM HOSPITAIS-REFERÊNCIA DE \\ TRAUMA NA CIDADE DE CURITIBA (PARANÁ, BRASIL)
}

\section{EPIDEMIOLOGÍA DEL TRAUMA RAQUIMEDULAR (TRM) EN HOSPITALES REFERENCIA DE TRAUMA EN LA CIUDAD DE CURITIBA (PARANÁ, BRAZIL)}

\author{
Francisco Alves de Araúso Junior, ${ }^{1}$ Anderson Matsubara, ${ }^{1}$ Luiz Henrioue Cardoso Perelira, ${ }^{1}$ Eric Henrioue Batista Schmidt, ${ }^{2}$ Gabriel Luiz de Souza Kondlatsch ${ }^{2}$ \\ 1. Hospital Universitário Evangélico Mackenzie do Paraná, Department of Neurosurgery, Curitiba, PR, Brazil. \\ 2. Faculdade Evangélica Mackenzie do Paraná, Curitiba, PR, Brazil.
}

\begin{abstract}
Objective: To outline the clinical-epidemiological profile of patients who were victims of SCT, to identify the main trauma mechanisms for this injury and its outcome. Methods: Retrospective cross-sectional study, in which the epidemiological data, computed tomography reports and medical records of patients with fractures identified in their examinations at trauma reference hospitals in Curitiba-PR, in 2018, were analyzed. Results: 705 patients were studied. There was a male prevalence (64\%), the most affected age group was 21 to 30 years old (18\%), the mean age was 48.23 years, the mean female age being approximately 10 years higher. The main mechanisms were traffic accidents (34\%), falls from a higher level (29\%) and falls from the same level (25\%). The most affected segment was the lumbar with $46 \%$ of cases. The incidence of surgical treatment was $15 \%$, of spinal cord injury was $5 \%$, and death was the outcome in less than 3\% of cases. Conclusion: The profile of the patient victim of SCT in 2018 in Curitiba-PR was that of a young man, victim of a traffic accident with thoracolumbar involvement without spinal cord injury, under conservative treatment. Level of evidence II; Retrospective Study.
\end{abstract}

Keywords: Spinal Injuries; Spinal Fractures; Spinal Cord Injuries; Epidemiology; Spine.

\section{RESUMO}

Objetivo: Traçar o perfil clínico-epidemiológico dos pacientes vítimas de TRM, identificar os principais mecanismos de trauma para esta lesão e seu desfecho. Métodos: Estudo transversal retrospectivo, em que foram analisados dados epidemiológicos, laudos de tomografia computadorizada e prontuários dos pacientes que apresentaram fratura em seus exames, nos hospitais-referência de trauma em Curitiba-PR, no ano de 2018. Resultados: Dos 705 pacientes estudados, houve prevalência masculina (64\%); a faixa-etária mais acometida foi de 21 a 30 anos (18\%); a idade média geral foi de 48,23 anos, sendo a média feminina aproximadamente 10 anos mais alta. Os principais mecanismos foram acidente de trânsito (34\%), queda de nível (29\%) e queda de mesmo nível (25\%). O segmento mais acometido foi lombar com 46\% dos casos; tratamento cirúrgico teve incidência de 15\%, lesão medular de 5\% e óbito foi desfecho em menos de 3\% dos casos. Conclusão: O perfil do paciente vítima de TRM no ano de 2018 em Curitiba-PR foi de um homem jovem, vítima de acidente de trânsito com acometimento toracolombar sem lesão medular, sob tratamento conservador. Nível de evidência II; Estudo Retrospectivo.

Descritores: Traumatismos da Coluna Vertebral; Fraturas da Coluna Vertebral; Traumatismos da Medula Espinal; Epidemiologia; Coluna Vertebral.

\section{RESUMEN}

Objetivo: Trazar el perfil clínico-epidemiológico de los pacientes víctimas de TRM, identificar los principales mecanismos de trauma para esta lesión y su resultado. Métodos: Estudio transversal retrospectivo, en el que fueron analizados datos epidemiológicos, laudos de tomografía computarizada e historiales médicos de los pacientes que presentaron fractura en sus exámenes, en los hospitales referencia de trauma, en Curitiba-PR, en el año 2018. Resultados: De los 705 pacientes estudiados, hubo prevalencia masculina (64\%); el grupo de edad más acometido fue de 21 a 30 años (18\%); la edad promedio general fue de 48,23 años, siendo el promedio femenino aproximadamente 10 años más alto. Los principales mecanismos fueron accidente de tránsito (34\%), caída de nivel (29\%) y caída del mismo nivel (25\%). El segmento más acometido fue el lumbar con 46\% de los casos; el tratamiento quirúrgico tuvo incidencia del 15\%, la lesión medular de $5 \%$ y la muerte fue resultado en menos del $3 \%$ de los casos. Conclusión: El perfil del paciente víctima de TRM en 2018 en Curitiba-PR fue de un hombre joven, víctima de accidente de tránsito con acometimiento toracolumbar sin lesión medular, bajo tratamiento conservador. Nivel de evidencia II; Estudio retrospectivo.

Descriptores: Traumatismos Vertebrales; Fracturas de la Columna Vertebral; Traumatismos de la Médula Espinal; Epidemiología; Columna Vertebral.

Study conducted at the Hospital do Trabalhador, the Hospital Universitário Cajuru, and the Hospital Universitário Evangélico Mackenzie, Curitiba, PR, Brazil.

Correspondence: Francisco Alves de Araújo Junior. Alameda Augusto Stellfeld, 1908, Bigorrilho, Curitiba, PR, Brasil. 80730-150. faraujojr@gmail.com 


\section{INTRODUCTION}

Spinal trauma accounts for only a small portion of all fractures, with a reported incidence of $4 \%$ to $23 \%$ in several epidemiological studies. ${ }^{1}$ However, their interference in the social, functional and financial situation of individuals may be more significant than other injuries as they contribute to disability with long-term consequences and healthcare costs. ${ }^{2}$ In 2004, the Unified Health System (SUS) registered 15,700 hospitalizations, with 505 deaths, resulting from spinal fractures, which required the involvement of multidisciplinary teams and high hospital costs. ${ }^{3}$ It is also estimated that patients with spinal cord injuries cost approximately $\$ 9.7$ billion each year in the United States. ${ }^{1}$

Spinal injuries without spinal cord involvement constitute most of these traumas. ${ }^{4}$ However, in the United States, approximately $15 \%$ of spinal trauma patients will have neurological impairment, and prevention remains the best strategy. ${ }^{5}$

Curitiba is the capital of Paraná, located in the south of Brazil. It is estimated that around 1.9 million people currently live in the city, but when the metropolitan region of Curitiba (RMC) is included, the number grows to around 3.6 million inhabitants. ${ }^{6}$ The capital of Paraná has 38 emergency care units through SUS, ${ }^{6}$ among them the 9 Emergency Care Units (UPAs) that provide care for low- and medium-complexity clinical emergencies. In addition to the UPAs there are the tertiary hospitals to provide care in highly complex cases, but only 3 tertiary hospitals in Curitiba-PR are approved by the Municipal Health Secretariat of Curitiba ${ }^{7}$ to provide care to trauma patients: Hospital do Trabalhador, Hospital Universitário Cajuru and Hospital Universitário Evangélico Mackenzie.

Thus, the objective of this study was to document the clinical-epidemiological profile of patients suffering from SCT and identify the main mechanisms of this trauma, in addition to possible outcomes, such as death, spinal cord injury and the treatments implemented, in reference trauma care hospitals in the city of Curitiba-PR in 2018.

\section{METHODS}

This is a retrospective observational study, in which the medical records, from the period between January and December 2018, from the emergency surgical care units of hospitals listed by the Municipal Health Secretariat of Curitiba as references in the treatment of trauma in the city of Curitiba-PR were reviewed. They are the Hospital do Trabalhador (HT), the Hospital Universitário Cajuru (HUC) and the Hospital Universitário Evangélico Mackenzie (HUEM). The study started after receiving a favorable opinion from the IRB of each participating hospital (CAAE HT: 08513018.3.3002.5225, CAAE HUC: 08513018.3.3001.0020. CAAE HUEM: 08513018.3.0000.0103).

The epidemiological variables of age and sex were evaluated in the three hospitals. Age was divided into eight categories: 20 or under, 21 to 30,31 to 40,41 to 50,51 to 60,61 to 70,71 to 80 , and 81 or over. The trauma mechanisms were classified into 7 categories: traffic accidents (TA), which includes car, motorcycle, and bicycle accidents, accidents involving pedestrians, collision between two or more vehicles and rollovers; aggression, which includes assaults in which punches, kicks and stab wounds (SW) were involved; gunshot wounds (GSW); higher level falls (HLF), including high-energy falls with associated with different levels; same level falls (SLF), falls from the same level, such as trips and slips; direct trauma (DT), when a spinal trauma occurs from an object in direct contact with the spine; and others, where mechanisms that did not fit into any of the other categories (shallow-water dive, for example) or traumas with no specific mechanism were allocated.

The spine was evaluated by its anatomical divisions: cervical, thoracic, lumbar and sacral. The levels of the spine fracture were also evaluated by distribution into high cervical fracture (C1 and C2), low cervical fracture (C3 to $\mathrm{C} 7$ ), high thoracic fracture (T1 to $\mathrm{T} 4$ ), middle thoracic fracture (T5 to T9), thoracolumbar fracture (T10- L2), low lumbar fracture (L3 to L5) and sacral fracture.

Patients being treated in the aforementioned hospitals during the period evaluated (January to December 2018, affected by SCT, as evidenced by the presence of a fracture in the computed tomography report, were included. Patients without fractures, or with non-traumatic fractures (for example, due to tumors and metastatic disease, metabolic causes, among others) or fractures that occurred outside of the period analyzed, patients who were not examined (due to death or refusal to undergo examination), patients whose CT reports were not filed in the internal hospital system and patients with incomplete medical report data were excluded.

The data were collected and cataloged in a spreadsheet using the Google Sheets (Google ${ }^{\mathrm{TM}}$ ) program. The variables analyzed were epidemiological data and data about the trauma mechanism, the therapy instituted, as well as possible outcomes (death or spinal cord injury).

Because it is a retrospective observational descriptive study that only used information available in medical records and institutional information systems, and clinical information available at the institution, in which the data were analyzed anonymously, and the results were presented in aggregated form, not allowing identification of the study participants, there was no need to use the ICF (Informed Consent Form)

\section{RESULTS}

A total of 9,752 computed tomography reports were analyzed. Eight thousand nine hundred and twenty-six $(8,926)$ reports were excluded for incompatibility with the study inclusion criteria, leaving 826 compatible with fracture in the vertebral segments, which correlated to 705 patients for epidemiological analysis.

Taking the three hospitals involved into account, the cases of SCT in the city of Curitiba-PR in 2018 can be estimated. Data analysis must consider that the number of patients did not necessarily correspond to the number of vertebrae affected, since depending on the mechanism and the age of the patient, there may be more associated fractures.

\section{Sex and Age Distribution}

Of the 705 patients, 451 (63.97\%) were men and 254 (36.03\%) were women. The mean overall age was 48.23 years with a standard deviation of \pm 20.62 years. The mean male age was 44.92 years, and the mean female age was 10 years higher at 54.09 years. It can be seen that over 71 years of age there is a female predominance (more than $60 \%$ of the patients in this age group are female), which leads to an increase in the mean female age. A peak incidence can also be observed in the 21 to 30 years of age group, which corresponds to $18.16 \%$ (12.91\% of the men and $5.25 \%$ of the women) of the total number of patients. (Figure 1)

\section{Trauma Mechanisms}

The main mechanism was the traffic accident, which was the cause of SCT in $33.76 \%$ of the patients. Next, higher level falls and same level falls accounted for $29.08 \%$ and $25.39 \%$ of the patients, respectively. These three mechanisms accounted for approximately $90 \%$ of the cases of SCT during the period analyzed. (Table 1)

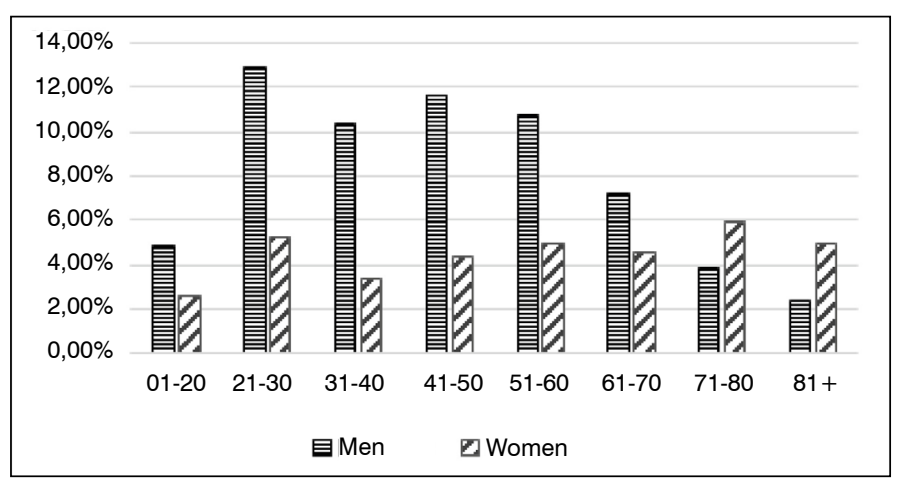

Figure 1. Incidence of the sexes within the age groups. 
Table 1. Incidence of the Trauma Mechanisms of SCT.

\begin{tabular}{c|c|c|c|c}
\hline Trauma Mechanism & No. of Patients (\%) & M:F Index & Mean Age & Fracture/Patient Index \\
\hline Traffic Accident & $238(33.76)$ & 2.13 & 47.40 & 1.99 \\
\hline Aggression & $22(3.12)$ & 6.33 & 30.68 & 1.41 \\
\hline GSW $^{*}$ & $22(3.12)$ & 4.5 & 49.42 & 1.55 \\
\hline Higher Level Fall & $205(29.08)$ & 2.73 & 64.45 & 1.86 \\
\hline Same Level Fall & $179(25.39)$ & 0.70 & 44.32 & 1.54 \\
\hline Direct Trauma & $34(4.82)$ & 2.78 & 49.40 & 2 \\
\hline Others & $5(0.71)$ & 1.5 & 48.23 & 1.8 \\
\hline Total & $705(100)$ & 1.78 & \\
\hline
\end{tabular}

${ }^{*}$ GSW: Gunshot Wounds

\section{Anatomical region}

Adding up the number of vertebrae affected by anatomical level, the lumbar spine was the most impacted, followed by the thoracic spine, the cervical spine and finally, the sacral region with less than $2 \%$ of the fractures. (Figure 2) Of the total 1253 vertebrae affected in the 705 patients, 569 fractures $(45.41 \%)$ were concentrated in the thoracolumbar transition (T10-L2). The peak of incidence in the first lumbar vertebra stands out, corresponding to 225 cases (17.96\%) in this specific vertebra. (Figure 3)

\section{Outcome}

As for the outcomes evaluated in this study, a predominance of conservative treatment was observed in $85.32 \%$ of the cases. Spinal cord injury was present in $5.05 \%$ and death occurred in $2.84 \%$ of cases.

\section{DISCUSSION}

When analyzing the distribution of vertebral traumas in Curitiba-PR by sex, a male predominance is evident, as expected according to Di Credo and Felix, ${ }^{8}$ with approximately $64 \%$ of cases. (Table 2)

In studies where the number of patients studied is significantly higher (above 500), the results are similar to those of the present study (705 patients). The German study by Leucht ${ }^{10}$ reported a percentage of males of $61.03 \%$, really close to that observed in this study $(64 \%)$. Wang ${ }^{11}$ showed a male rate of $65.5 \%$, close to that observed in this study.

We observed a difference of 10 years between the mean ages of the males and female patients. This involvement in an older female population was also observed in the Dutch study by Den Ouden ${ }^{12}$ in which the mean age of the men was 48.9 years and of the women was 56.4 years. These data point to a probable correlation with the higher incidence of osteopenia/osteoporosis in women.

The studies of Brito ${ }^{3}$ and De Campos, ${ }^{5}$ were two Brazilian studies with less than 100 patients, which obtained an approximate mean age of 35 years, a mean less than that found in the present study (48.23 years). The German study ${ }^{10}(n=562)$, obtained a mean age of 43.8 years, while the Dutch study ${ }^{12}(n=1470)$ reported a mean age of 52 years. (Wang ${ }^{11}(n=3142)$ got a mean age of 45.7 years, close to that found in this study (48.3 years).

Studies in the national literature showed that the highest incidence was in the 21 to 30 years of age group,, $, 5,9$ just as observed in the present study, followed by the 30 to 40 years of age group.

Regarding the mechanisms analyzed, traffic accidents had the highest incidence, accounting for approximately one third of the cases. (Table 1) These data differ from those of large studies in the literature ${ }^{10-12}$ conducted in other countries (Germany, ${ }^{10}$ China, ${ }^{11}$ the Netherlands ${ }^{12}$ ) that found higher level falls to be the main mechanism of trauma.

However, this mechanism is presented as the second most common, followed by same level falls. In addition, these three mechanisms account for approximately $80 \%$ of the cases in the studies cited, ${ }^{10-12}$ being similar to the present study, in which they account for $88.23 \%$ of the cases.

Other national studies ${ }^{5,13}$ also reported results similar to those

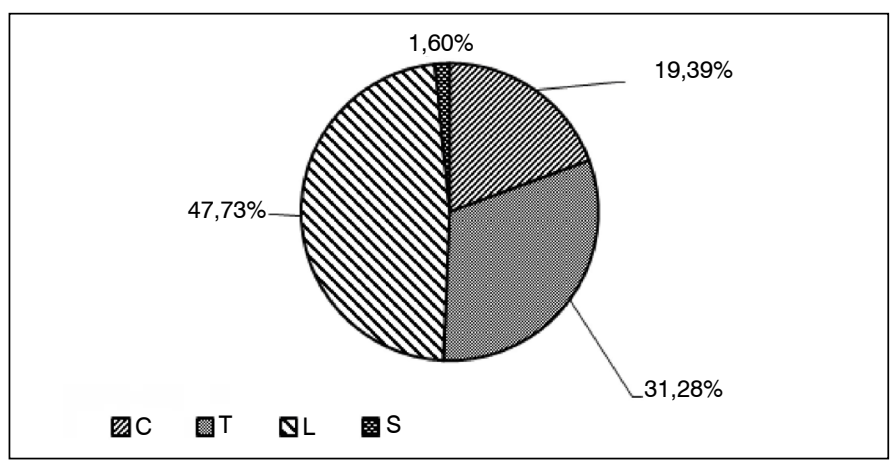

Figure 2. Incidence of SCT involvement by anatomical level.

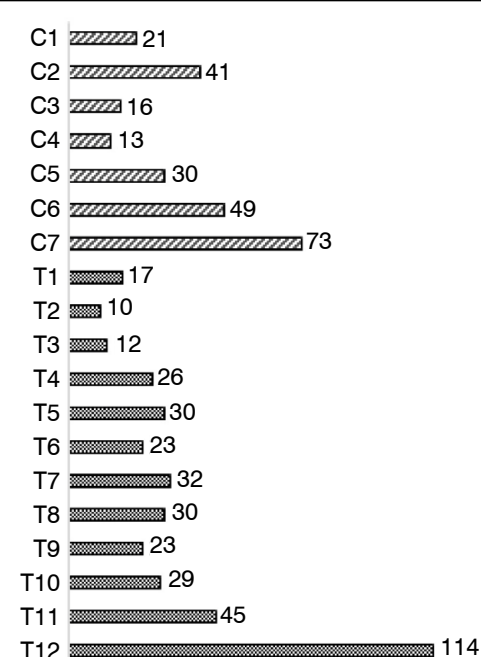

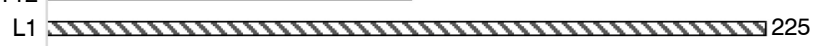

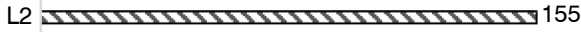

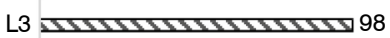

L4 $503 \times 13 \times 130 \times 14$

L5 $\ln \ln 40$

$\mathrm{S}$ ㅍㅛㅛㅛㅛㅛ 20

Figure 3. Incidence of SCT involvement by vertebra.

Table 2. Number of patients and incidence of male patients in the Spinal Cord Trauma studies.

\begin{tabular}{c|c|c}
\hline Study & No. of patients & Male \\
\hline De $\operatorname{Campos}^{5}(2008)$ & 100 & $86 \%$ \\
\hline Brito $^{3}(2011)$ & 87 & $81.6 \%$ \\
\hline Solino $^{9}(1990)$ & 240 & $75 \%$ \\
\hline Leucht $^{10}(2009)$ & 562 & $61.03 \%$ \\
\hline Wang $^{11}(2012)$ & 3142 & $65.5 \%$ \\
\hline Present Study & 705 & $64 \%$ \\
\hline
\end{tabular}


of the international studies cited with the fall mechanism in first place. However, in these studies there was no separation between high-energy falls and same level falls.

The greatest involvement of the lumbar level, with emphasis on the thoracolumbar transition, is also compatible with other studies in the literature, ${ }^{5,11,14}$ but differs from the Dutch article ${ }^{12}$ in which there was greater involvement of the thoracic level with a significant $42.8 \%$ of cases.

Two peaks in the incidence of affected vertebrae can be observed, the first formed by T12, L1 and L2 $(114,225$ and 155 cases, respectively) and a second formed by the low cervical segment, with C7 most often affected (72 cases) followed by C6 and C5 (49 and 30 cases, respectively).

A similar pattern can be observed in the Dutch study, ${ }^{12}$ where even though the thoracic level was predominant (42.8\%), a peak of incidence can be observed in the thoracolumbar transition with emphasis on the first lumbar vertebra. This peak of incidence in the thoracolumbar transition was also observed in several studies ${ }^{10,11,14-16}$ including the present study, regardless of whether there was a lumbar or thoracic predominance in the study.

This pattern of involvement reflects the mobility of the spinal transition regions, which predisposes them to fracture. ${ }^{14}$ One explanation for this vulnerability is the contraposition of the stability of the thoracic cavity and its costotransverse ligaments, in contrast to the more flexible and less protected subadjacent regions. ${ }^{17}$

Fractures in the transitional junctions of the spine have different causes. ${ }^{10}$ The cervical-thoracic transition is most commonly fractured in traffic accidents and sports accidents due to the fact that this transition is more susceptible to acceleration and deceleration because its muscle apparatus is thinner in this region, On the other hand, fractures of the thoracolumbar transition are mainly due to falls. Because the muscle apparatus of this region is robust, the transition ends up being more protected from forces of distraction (such as traffic accidents, for example), but this region is much more prone to compression fractures, due to the great weight acting on each vertebra, which may be responsible for the large number of lumbar fractures associated with falls.

\section{CONCLUSION}

The epidemiological profile of the patients affected by SCT in the three trauma care hospitals in the city of Curitiba-PR was male patients with a mean age of 45 years and female patients with a mean age approximately 10 years higher. The most related mechanisms were traffic accidents, followed by higher level falls and same level falls. The most affected segment was the thoracolumbar transition, mainly the L1 vertebra. The predominance of conservative treatment in approximately $85 \%$ of cases was also observed.

All authors declare no potential conflict of interest related to this article.

CONTRIBUTION OF THE AUTHORS: Each author made significant individual contributions to the manuscript. AM: Active participation in the discussion of the results, writing and review; EHBS: Preparation of the entire research project, data collection, writing, review and active participation in the discussion of the results; FAAJ: Active participation in the discussion of the results, intellectual concept and review; GLSK: Preparation of the entire research project, data collection, review and active participation in the discussion of the results; LHCP: Review and active participation in the discussion of the results.

\section{REFERENCES}

1. Oliver M, Inaba K, Tang A, Branco BC, Barmparas G, Schnüriger B, et al. The changing epidemiology of spinal trauma: A 13-year review from a Level i trauma centre. Injury. 2012:43(8):1296-300. doi: 10.1016/.injury.2012.04.021.

2. Oner C, Rajasekaran S, Chapman JR, Fehlings MG, Vaccaro AR, Schroeder GD, et al. Spine Trauma-What Are the Current Controversies? J Orthop Trauma. 2017;31(9):1-6. doi: 10.1097/BOT.0000000000000950.

3. Brito LMO, Chein MBC, Marinho SC, Duarte TB. Avaliação epidemiológica dos pacientes vítimas de traumatismo raquimedular. Rev Col Bras Cir. 2011;38(5):304-9. doi: 10.1590/ S0100-69912011000500004

4. Tuono VL. Traumas de coluna no Brasil : análise das internações hospitalares Traumas de coluna no Brasil : análise das internações hospitalares [Dissertação de mestrado]. Universidade de São Paulo; 2008.

5. Campos MF, Ribeiro AT, Listik S, Pereira CAB, Andrade Sobrinho J, Rapoport A. Epidemiology of spine injuries. Rev Col Bras Cir. 2008;35(2):88-93.

6. Instituto Brasileiro de Geografia e Estatística. Demografia de Curitiba [Internet]. 2019 [cited 2020 Mar 7]. Available from: https://cidades.ibge.gov.br/

7. Secretaria Municipal de Curitiba. Atenção Especializada ao Trauma [Internet]. 2018 [cited 2020 Mar 11]. Available from: http://www.saude.curitiba.pr.gov.br/atencao-especializada.html

8. Credo PFD, Felix JVC. Perfil Dos Pacientes Atendidos Em Um Hospital De Referência Ao Trauma Em Curitiba: Implicações Para a Enfermagem. Cogitare Enferm. 2012;17(1):12631. doi: $10.5380 /$ ce.v17i1.26385.
9. Solino JL, Melo MFFV, Silva DHA, Elias N. Traumatismos da coluna vertebral: avaliaçäo de etiologia, incidência e freqüência. Rev Bras Ortop. 1990;40:1-4.

10. Leucht $P$, Fischer K, Muhr G, Mueller EJ. Epidemiology of traumatic spine fractures. Injury. 2009:40(2):166-72. doi: 10.1016/j.injury.2008.06.040

11. Wang $H$, Zhang $Y$, Xiang $Q$, Wang $X$, Li C, Xiong H, et al. Epidemiology of traumatic spinal fractures: Experience from medical university-affiliated hospitals in Chongqing. China,2001-2010:Clinical article. J Neurosurg Spine. 2012;17(5):459-68. doi: 10.3171/2012.8.SPINE111003.

12. Ouden LPD, Smits AJ, Stadhouder A, Feller R, Deunk J, Bloemers FW. Epidemiology of spinal fractures in a level one trauma center in the netherlands: A 10 years review. Wolters Kluwer Heal. 2019;44(10):732-9. doi: 10.1097/BRS.0000000000002923.

13. Koch A, Graells XS, Zaninelli EM. Epidemiologia de fraturas da coluna de acordo com o mecanismo de trauma: análise de 502 casos. Coluna/Columna. 2007:6(1):18-23.

14. Oliveira PAS, Pires JV, Borges Filho JMM. Traumatismos da coluna torácica e lombar: avaliaçäo epidemiológica. Rev Bras Ortop. 1996;31(9):771-6.

15. Caracostas M. Fractures of the dorso-lumbar spine. Gaz Med Fr. 1960;67:1151-6.

16. Reinhold M, Audigé L, Schnake KJ, Bellabarba C, Dai LY, Oner FC. AO spine injury classification system: A revision proposal for the thoracic and lumbar spine. Eur Spine $\mathrm{J}$. 2013;22(10):2184-201. doi: 10.1007/s00586-013-2738-0.

17. Jacob Junior C, Barbosa DM, Batista PR, Vieira DM, Machado IC, Rezende R. Fratura toracolombar do tipo explosão: O que o radiologista deve conhecer. Radiol Bras. 2012;45(2):1014. doi: 10.1590/S0100-39842012000200008. 